\title{
Global Solidarity, Global Worker Empowerment, and Global Strategy in the Anti-sweatshop Movement
}

\author{
Matthew S. Williams \\ Loyola University Chicago, mwilliams26@luc.edu
}

Follow this and additional works at: https://ecommons.luc.edu/soc_facpubs

Part of the Sociology Commons

Author Manuscript

This is a pre-publication author manuscript of the final, published article.

\section{Recommended Citation}

Williams, Matthew S.. Global Solidarity, Global Worker Empowerment, and Global Strategy in the Antisweatshop Movement. Labor Studies Journal, 45, 4: , 2020. Retrieved from Loyola eCommons, Sociology: Faculty Publications and Other Works, http://dx.doi.org/10.1177/0160449X20937466

This Article is brought to you for free and open access by the Faculty Publications and Other Works by Department at Loyola eCommons. It has been accepted for inclusion in Sociology: Faculty Publications and Other Works by an authorized administrator of Loyola eCommons. For more information, please contact ecommons@luc.edu. c) (†) $\ominus$

This work is licensed under a Creative Commons Attribution-Noncommercial-No Derivative Works 3.0 License. (c) Sage, 2020. 
Global Solidarity, Global Worker Empowerment, and Global Strategy in the Anti-Sweatshop Movement

by

$$
\begin{gathered}
\text { Matthew S. Williams } \\
\text { Department of Sociology } \\
\text { Loyola University Chicago } \\
1032 \text { West Sheridan Road } \\
\text { Chicago IL 60660 } \\
\text { 773-508-3298 } \\
\text { mwilliams26@luc.edu }
\end{gathered}
$$

Biography: Dr. Matthew S. Williams is a lecturer in the Department of Sociology and the Global and International Studies Program at Loyola University Chicago. His book Strategizing Against Sweatshops: The Global Economy, Student Activism and Worker Empowerment was recently published by Temple University Press.

\begin{abstract}
I explore the ideology of worker empowerment among US anti-sweatshop activists, particularly United Students Against Sweatshops, and its strategic consequences for transnational campaigns. This ideology is central in shaping the movement's transnational strategy and organization, fostering communication and accountability, particularly to organizations representing sweatshop workers. Such organizational choices in turn shape how transnational networks strategize. For example, the anti-sweatshop movement rarely uses the familiar tactic of boycotts, due to opposition from workers. The more empowered sweatshop workers at in such networks, the more informed decisions their allies can make, and the more strategically effective the movement can be.
\end{abstract}

The period since the 1970s has seen the resurgence globally of a disturbing phenomenon that many observers had assumed was largely eliminated—sweatshops. In many major industries 
worldwide, workers, mainly young women, are forced to work long hours for little pay, often in unsafe conditions under the supervision of abusive managers (Anner 2011; Bonacich et al. 1994; Gereffi and Korzeniewicz 1994; Ross 2004). As a solution, many companies and industry associations have promoted corporate social responsibility (CSR) programs. Research on CSR programs, however, shows that they rarely work effectively (Barrientos and Smith 2007; Esbenshade 2004; Locke, Amengual, and Mangla 2009; O'Rourke 2003; Pearson and Seyfang 2001; Rodríguez-Garavito 2005; Seidman 2007; Tsogas 2009; Wells 2007). A striking example of this is Locke, Qin and Brause's (2007) study of Nike's CSR program, using data provided by Nike, a "data set based on factory audits of over 800 of Nike's suppliers located in 51 different countries" (p. 20). Given the source of the data, the results should, if anything, be biased in favor of Nike — but they show that Nike's programs are ineffective, with some factories improving, but others remaining the same or getting worse. "Interviews with other global brands, NGO representatives, and leaders of the major multi-stakeholder initiatives indicate that Nike's experience with monitoring is by no means unique" (p. 21).

In response, activists have forged a new, transnational anti-sweatshop movement to challenge the transnational corporations whose policies promote sweatshops across the globe. Given the odds against them, the anti-sweatshop movement has achieved a surprising degree of success. In this paper, I argue that this success is rooted in significant measure in the fact that US anti-sweatshop advocates such as the ones I interviewed for my research—principally members of United Students Against Sweatshops (USAS) and the Worker Rights Consortium (WRC)have worked hard to forge ties based on the principle of solidarity with the sweatshop workers they seek to help. This is in turn rooted in the anti-sweatshop movement's ideology of worker empowerment $-\mathrm{a}$ belief that the best way to fight sweatshops is to empower workers, 
specifically through independent, democratic labor unions that represent those workers.

Because groups such as USAS emphasize the importance of empowering workers through such unions, it is important to them to include representatives of workers, including both their unions and allied labor NGOs from the Global South, in the leadership of campaigns meant to help them and to let these workers set the priorities of the movement. The goal is for participants in the movement to make major decisions democratically, in a way that they are accountable to representatives of the workers they seek to help. Thus, their ideology has a significant impact on their organization.

This ideology and organization in turn has a significant effect on their strategy. This is most visible in the fact that US anti-sweatshop activists have ended up rejecting, except in rare circumstances, one of the tools most progressives might initially assume were appropriate to this sort of issue - boycotting companies using sweatshops. While willing to use boycotts in certain narrow circumstances, the activists I interviewed have concluded that this familiar tactic is not, in most cases, the most effective means of fighting sweatshops. US groups' goal of solidarity with and accountability to labor rights groups in the Global South was a central factor in this strategic choice. Most workers oppose boycotts, which they fear will put them out of work altogether, rather than achieving their goal of improving their working conditions to ones where they are treated with dignity, make a living wage, can form a union, and so forth. In other words, a commitment to empowerment fosters more communication between sweatshop workers and their allies in the Global North. Because the Northern groups are making strategic decisions informed by workers' knowledge of conditions on the ground and their own understanding of their needs and aspirations, this leads the movement's strategy to be more effective. Avoiding boycotts is a negative example of this, in the sense that it involves avoiding a strategy that would 
harm workers, but we will look at positive examples below, where US anti-sweatshop groups have designed strategies around feedback from sweatshop workers about what issues they most urgently need help with.

There has been extensive research on the sort transnational advocacy and activist networks I look at in this paper, but not at the role of ideology in their structure and strategy. Some researchers (Van Dyke and McCammon 2010; Von Bülow 2010; Wood 2005) have looked in detail at the role of framing ideas as strategic tools used by transnational activists against their foes and/or how a shared set of beliefs strengthens transnational coalitions, but not the issues of organization and strategy, particularly as they relate to worker empowerment, that I focus on here. Several scholars (Downey and Rohlinger 2008; Epstein 1991; King 2008; Williams 2016, 2020) have argued, however, that ideology is an important component in how movements strategize, shaping not only the goals for which social movement organizations strive, but what they think is the best means to get there. For instance, Maney (2012) looks at the civil rights movement in Northern Ireland in the 1960s and the way activists split along ideological lines in response to concessions on civil rights issues offered by the British government. Those who operated from within an ethnic/ civil rights framework accepted the concessions and agreed to a moratorium on further protests; conversely, socialists who saw the fundamental issues as class conflict did not see the concessions as adequate and refused to agree to the moratorium, creating a strategic fissure in the movement. Looking at the anti-sweatshop movement's ideology will help us better understand the how the movement is organized and how it strategizes — and how making worker empowerment central to their organization and strategy has been central to their success. 


\section{Two Anti-Sweatshop Monitoring Paradigms in Comparison}

\section{The Rise of Sweatshops}

The dramatic worldwide rise in sweatshop working conditions is broadly linked to the promotion of economic globalization by business and governments since the 1970s. More specifically, it is the result of a particular strategy by companies in many industries, that of overseas outsourcing. In outsourcing, lead firms (as the dominant corporations are often referred to in the global value chain literature, e.g. (Gereffi and Lee 2016; Gereffi and Luo 2016; van der Ven 2018)) contract out important parts of production to other, smaller firms, many of which in turn operate globally; companies based in Taiwan, South Korea and Hong Kong may, for instance, have factories in Southeast Asia and Central America. These contractors are then pitted against each other in a bidding war. They each try to secure business from the major firms by offering to do the production for the lowest possible cost, while still maintaining a certain quality. The burden for this reduction in costs is almost inevitably shifted onto workers, creating pervasive sweatshop conditions in most labor-intensive industries operating globally. The industry that in many ways pioneered this outsourcing model was the apparel business, where it is now the norm to outsource most or all production, while the major firms focus on the more profitable activities of design and marketing. Since the apparel industry has been the pioneer in outsourcing and therefore in reintroducing sweatshops, it has been the main target of the antisweatshop movement (Anner 2011; Bonacich et al. 1994; Gereffi and Korzeniewicz 1994; Ross 2004).

\section{United Students Against Sweatshops and the Worker Rights Consortium}

One of the key anti-sweatshop groups in the period I focus on (roughly 1997-2007) was 
United Students Against Sweatshops. USAS focused on the licensing agreements many colleges and universities had with various apparel companies, giving the apparel firms the right to produce clothing with the school's name and logo on it; in return, the university gets roughly 7 $8 \%$ of the profits. Through a series of campus-based campaigns beginning in 1997, USAS first pressed a number of colleges into setting up pro-labor codes of conduct for their licensees and then to join the Worker Rights Consortium, which would serve as an independent monitor of these codes. The licensees affected by these agreements included major apparel companies such as Nike and Reebok, who value their contracts with colleges for their potential to build long-term brand loyalty among college students (Benjamin 2000; Kniffin 2000; Slaughter and Rhoades 2004). These licensing agreements therefore give USAS a good deal of potential leverage over the companies involved.

It should be stressed that part of what makes both USAS and the WRC strategically effective is that they are separate organizations with a clear division of labor between them. While USAS as a student activist group mobilizes people to protest, the WRC as a representative of its member colleges engages in monitoring of their licensees and publishing reports on their inspections. When the WRC finds that licensees are noncompliant with colleges' codes of conduct and unwilling to take the necessary steps to rectify the matter, USAS can use the WRC's reports to legitimize their protests. The WRC itself, however, does not engage in protest.

USAS designed the WRC as an alternative to the Fair Labor Association (FLA), an organization a number of college administrators had their schools join when USAS initially called for them to abide by pro-labor codes of conduct. USAS' objections to the FLA were rooted in the fact its member also included — and most of the organization's money came from— the very apparel firms it was supposed to monitor, creating an inherent conflict of interest (Anner 
2012; Esbenshade 2004).

\section{USAS, the WRC, and the Kukdong Campaign}

A key event in the history of USAS, the WRC and the larger anti-sweatshop movement was the campaign starting in January 2001 focusing on Kukdong, a South Korean-owned factory in Mexico, where the workers were struggling to unionize and secure decent working conditions. The employer responded by firing the workers' leaders and calling in the police to brutally put down a strike. In their struggle against this, some of the workers' most important allies were US groups, such as the AFL-CIO Solidarity Center and USAS. I chose the Kukdong campaign as an example because it was among the best documented, both in my interviews (for details, see the methods section below) and written sources (Hermanson 2009; Ross 2006; Worker Rights Consortium 2001). It was also pivotal in the history of USAS and the WRC, since it was one of the first major effort to enforce colleges' labor standards that the two groups were involved inand the one that proved their effectiveness. The transnational network of groups involved in the Kukdong campaign is fairly typical of what one sees in other, similar anti-sweatshop campaigns involving USAS and their allies, in that it includes a wide range of US and other Northern groups allied with labor unions, labor rights NGOs and human rights groups in the Global South.

The seriousness with which many US anti-sweatshop activists take building transnational ties can be seen in the fact that one USAS member, Evelyn Zepeda, spent the duration of the Kukdong campaign living in the local village of Atlixco with one of the workers' leaders, Marcela Muñoz, where she "facilitated direct Internet-based communication between workers and USAS" (Ross 2006), making sure that USAS would have regular contact with the workers and thus be able to coordinate their strategy with them. She later also coordinated a visit by a 
student delegation to Atlixco, who stayed for the summer and wrote a report on the situation that was circulated on USAS' listserv (Ross 2004). This is striking because most of USAS's actual efforts were focused in the US, using the power they had built up on college campuses to pressure the Kukdong factory's main patrons, Nike and Reebok. USAS took this step of sending a member to live with the Kukdong workers because of the high value they-and most other US anti-sweatshop groups - place on transnational solidarity and accountability to sweatshop workers in order to empower them in global networks.

Eventually, the pressure from this campaign lead the apparel giants to in turn pressure the owners of Kukdong to finally recognize the workers' unions and engage in good-faith collective bargaining with them in September 2001, nine months after the start of the campaign. The new contract protected the workers from management harassment and gave them a $38 \%$ bonus, a de facto quite substantial raise. This was possible because USAS had achieved the commitment of a critical mass of schools to codes of conduct and their enforcement by the WRC. They could then use this institutional consumer power to threaten Nike and Reebok with the loss of their contracts if they did not in their turn pressure Kukdong's management to clean up their act. As a result of this pressure from US groups, Nike and Reebok in turn put pressure on Kukdong's management, leading to the September 2001 victory.

\section{The Fair Labor Association and the Case of Choishin}

We can contrast the way USAS, in its activist role, and the WRC, in its role as an official labor rights monitor for universities, handled the situation at Kukdong with the way the industrybacked FLA operates. The lead firms typically shift blame for sweatshops onto their contractors, claiming they are powerless to fix the problem, given the pervasiveness of sweatshop use among 
contractors. Firms promoting corporate social responsibility programs like the FLA see them as a means of holding contractors accountable not to their workers, but the lead firms; and typically view such programs as a substitute for labor unions. The impact of these differences can be seen in a number of things. For instance, though both the WRC and FLA include freedom of association (i.e., the right to an independent union) and the right to collectively bargain in their codes of conduct, there are dramatic differences in their practices in this regard. In their operations, the FLA emphasizes protective rights - decent health and safety standards, levels of pay, reasonable overtime hours, etc.- but not enabling rights such as freedom of association, collective bargaining, and freedom from discrimination. The WRC, on the other hand, emphasizes both protective and enabling rights (Anner 2012; Barrientos and Smith 2007; Rodríguez-Garavito 2005). In their monitoring programs, the WRC makes unannounced inspections, guarantees workers confidentiality to protect them from retaliation, and publishes all their reports publicly; the FLA initially followed none of these practices, though, after outside criticism, they did address some of these problems (Esbenshade 2004; Rodríguez-Garavito 2005).

Rodríguez-Garavito (2005) contrasts the case of Kukdong with another one, where the WRC was not involved, but monitoring was instead spearheaded by the FLA — Choishin, a South Korean owned two-factory complex in Guatemala City whose main patron was Liz Claiborne. After organizing clandestinely for two years, workers announced their unionization in July 2001. Within days, lawyers working for management were telling workers if they continued to unionize, the factory would shut down. Union leaders were attacked inside the factory by management-backed thugs, who intimidated them into signing resignation letters. Liz Claiborne and the FLA intervened at this point - the union leaders who had been forced to resign were 
allowed to return to work and the union to openly operate. Up till this point, the story is roughly parallel to the one at Kukdong. However, at Choishin, while the union continued to operate, it was reduced to something that Choishin's management considered only a minor annoyance, not a threat to their power, certainly not a group they had to sit down and collectively bargain with, a very different outcome than the eventual success of the union at Kukdong. This situation changed in 2003, not as a result of the actions of the FLA or Liz Claiborne, but the Guatemalan Ministry of Labor, which threatened to close the factory for labor law violations if management did not negotiate with the union. The impetus for this was the Guatemalan government's desire to join the US-Central American Free Trade Agreement, which visible labor problems like those at Choishin stood in the way of.

While Rodríguez-Garavito's ethnography of the Choishin campaign is the only study of that campaign, his findings square with other empirical analyses of the FLA's operations. For instance, Anner's (2012) analysis of 805 FLA inspection reports finds that, despite the fact that the FLA has detailed standards for freedom of association and collective bargaining, in practice

they do a very weak job of protecting workers' right to unionize. Based on an in-depth review of the FLA's organization and operations, Sethi and Rovenpor (2016) argue that the FLA is not only underfunded and understaffed, but that it lacks accountability to the workers it is supposed to help and is largely controlled by its corporate members; consequently, it its approach to monitoring is not very effective.

\section{Comparing the WRC and the FLA}

The WRC and FLA have very different relationships with both apparel firms and organizations, such as labor unions and labor rights NGOs, with ties to the workers whose 
interests they are supposed to be protecting. As noted above, the FLA has close ties to corporations - one-third of their board members represent corporations and much of the FLA's funding comes from them, resulting in grave conflicts of interest that make the organization ineffective as a monitor (Anner 2012; Esbenshade 2004 182). Lynda Yanz of the Maquila Solidarity Network (MSN), a leading anti-sweatshop group, served on the board of the FLA from 2009-2013. She resigned in 2013 after the FLA refused to change their code of conduct to strengthen their complaints procedure and include representation from labor unions and labor rights NGOs, saying, the "FLA operates more as an industry organisation than as a multistakeholder initiative," and, "When it turned out that [the] FLA did not wish to implement structural changes on the latter two points, MSN stepped out. We felt like a voice crying in the wilderness" (Good Electronics 2013). In contrast to the FLA, the WRC's bylaws do not allow corporations to have membership or donate money to avoid such conflicts of interest. One USAS member I interviewed (see the methods section below)—who requested anonymity—said, "The WRC just represents universities, they're multi-university. The fact that they're independent of industry allows the WRC to be more aggressive in pressing companies because no one has veto power over what they do publicly. All these other [monitoring] organizations, either through formal or informal means, there are very powerful voices of the companies in determining what gets said, what gets done."

The FLA itself has no extensive ties with labor rights organizations and most of the NGOs on their board have, at best, weak connections with the labor movement. Those that do have strong connections, like the Maquila Solidarity Network, have generally not stayed involved for long (Anner 2012; Esbenshade 2004 182). While the WRC does not take money from unions in order to avoid any appearance of a conflict of interest (Worker Rights 
Consortium 2019a)(Jeremy Blasi, Laura McSpedon, interviews, 2007), one-third of their board consists of USAS members and another third of independent labor rights experts, both of whom have the trust of the labor movement (Worker Rights Consortium 2019b). Indeed, the WRC has their own network of ties with labor unions and labor rights activists, relying on them to alert the WRC of labor rights violations in factories where they can perform inspections (generally those producing collegiate apparel) and drawing on this network for members of their inspection and monitoring teams (Jeremy Blasi, Agatha Schmaedick, Nancy Steffan, interviews, 2007).

Auret van Heerden, the former executive director of the FLA, views the FLA and WRC as having complementary approaches, the WRC benefiting from its connection to workers, the FLA from its connection to corporations: "The WRC has great connections on the ground and an early-warning system that is invaluable at times. There is an obvious synergy emerging. They can uncover problems. We can get the brands to get us both in the door" (quoted in Esbenshade 2004). Something noteworthy in van Heerden's words is an implicit acknowledgement that the FLA has few ties to the workers they are officially meant to be helping.

Rodríguez-Garavito (2005) argues about the Choishin case,

[D]ifferent monitoring systems create different opportunities for the exercise of countervailing power and worker organizing. The mechanisms embedded in the WRC system to put pressure on target actors and sustain it over time entailed a more propitious institutional context for the thriving of the Kukdong union than the mechanisms of the FLA did in the Choishin case. Whereas Kukdong workers could count on mobilized consumers (U.S. college students organized by USAS) effectively represented by the umbrella monitoring organization (the WRC) to keep the pressure beyond the initial strike and negotiations, the fact that the 
umbrella organization in the Choishin case (the FLA) sets less stringent

conditions on its member firms, together with the fact that it does not embody

continued pressure from organized consumers, meant that the initial opportunity

for the formation of the union could not be sustained and expanded so that the

union could increase its membership and get a contract. Absent sustained,

institutionalized pressure, the Choishin management resorted to more subtle but

equally effective union-busting strategies while Liz Claiborne could claim to be in

full compliance with its code of conduct (p. 256).

\section{Power in Transnational Activist Networks}

An increasing body of work on transnational activism looks into the question of the inequalities in power that typically exist between the Northern and Southern wings of these networks and the impact this has on their campaigns. If these campaigns are well organized and the Northern activists make an effort to coordinate with their Southern counterparts, such transnational campaigns can be empowering to Southern grassroots groups (Friedman 2009). But activist groups in the Global North typically have far more resources at their disposal and this can shape who gets included in transnational coalitions, which issues the networks campaign around, and how these issues are framed (Bandy and Smith 2005; Bob 2001; Pallas 2017; Wood 2005). A number of scholars have argued that the Northern members of such networks are not always accountable to and representative of the constituencies they are supposedly trying to help (Anderson 2000; Pallas 2017; Steffek and Hahn 2010).

The FLA — which likes to represent itself as part of the anti-sweatshop movement, even if it has weak organizational ties with other anti-sweatshop groups - is a strong case of many of 
these problems, as can be seen in how they operated and their lack of effectiveness in the Choishin case. Without ties to the workers, they are neither representative of or accountable to them - instead, they are most accountable to their corporate members. In so far as the FLA can be said to have a strategy to fight sweatshops, this strategy is ineffective, in that it seeks to leave power in the hands of the lead firms instead of empowering sweatshop workers. It therefore omits sweatshop workers' own needs and aspiration from the agenda and leaves them unable to protect their own rights. This is in contrast to USAS and the WRC's efforts in the Kukdong campaign and elsewhere, in which they have actively cultivated ties that make them accountable to groups like labor unions and labor rights NGOs that are representative of workers. USAS went so far as to have a member stay with the Kukdong workers for the duration of that campaign in order to facilitate communication and coordinate strategy - to try to ensure that USAS was actually empowering the workers at Kukdong. The FLA, with no grassroots base and strong institutional pressures from its corporate members not to disturb the established social order in the global production system, did little to help the workers at Choishin, only gaining their union symbolic recognition, but no real bargaining power. When everything is taken into consideration, the FLA prioritizes the need of its corporate members to make profits by taking an approach to monitoring that does not require its member businesses to make any changes to the outsourcing practices that produce sweatshops in the first place. USAS and the WRC, on the other hand, embedded in a transnational network of workers' rights groups and labor unions, are much more focused on the changes that need to happen to help empower workers to meet their needs and achieve their aspirations, even if that means USAS engaging in confrontational activism.

Many of the discussions of accountability and representativeness in transnational movement networks emphasize the importance of these principles in normative terms. While this 
clearly matters, I want to look at what impact such accountability and representativeness have on the transnational network's strategy and the success of that strategy. A number of scholars have found democratic organization and decision-making — organization that empowers all members - enhance a movement's strategic capacity, by bringing a wider range of experiences and ideas into play when formulating strategy, thus fostering creativity and innovation (Ganz 2009; McCammon 2003, 2012; Staggenborg 1989). Organization matters for the development of strategy--and ideology in turn informs both organization and strategy, including which members of a network are empowered.

\section{Ideology and Movements}

The most frequently used concept to describe ideas in the social movements literature is framing. A number of scholars (Ferree and Merrill 2004; Oliver and Johnston 2000; Westby 2002; Zald 2000), however, argue that the concept of framing, while valuable, has been overextended and emphasize the importance of understanding ideology's role in how movements formulate strategy. Ferree and Merrill (2004) argue that a more nuanced analysis can be developed by using the concepts of discourse, ideology, and framing together in social movement analysis. They define discourses as broad systems of communication that link a system of concepts together by means of an underlying logic. Discourses - that of human rights

for example — are always being contested and negotiated because different groups with different interests and values use the same discourse in attempts to communicate with each other and potential supporters. Ideologies are narrower than discourses--they are a coherent set of ideas organized around a particular set of values and a vision of how the world should be. Most narrow is a frame and the process of framing, which draws on discourses and ideologies to develop a particular way of defining an issue that activists can use strategically to mobilize people. While 
an ideology constitutes activists' worldview and guides them in developing strategy, a frame is conversely a set of ideas strategically deployed by activists to build their movement — and, at times, they may choose to frame in ways that are not entirely consistent with their ideology to build a broader base of support for the movement (Westby 2002).

In this paper, I follow Oliver and Johnston's (2000) definition of ideology, which looks at how three major elements are linked-1) a core set of values, 2) a theory about how the social world works, and 3) norms for taking action in the world in the light of these values and theory. I use this definition because of its utility as a heuristic device, making it easy to unpack and compare ideologies by breaking them down into these three elements. Unlike some theorists (e.g., Downey 1986; Ferree 1992), Polletta (2005) argues that we should not look at ideology as something expressive that competes with instrumental assessments of a situation in shaping a movement's actions. Rather, she argues that what activists see as instrumentally effective involves a value-laden process of cultural interpretation. Activists (and other social actors) can't interpret the social world around them in order to determine how to take action without an ideology to use as a lens to see the social world through (Blyth 2002; Williams 2016, 2020)\}.

\section{Methods}

My analysis draws on two major sources of data. The first is thirty in-depth interviews with activists and advocates in the US anti-sweatshop movement, conducted between June and October 2007. I started with a group of initial contacts, former and present leaders of the antisweatshop movement, who I was referred to; from there, I used snowball sampling to expand my range of contacts and interviewees. My selection of interviewees was guided by the need to create what Weiss (1994) calls a panel of knowledgeable informants_people who have 
participated in the events I am interested in and have otherwise difficult to obtain knowledge, in this case about how strategic decisions were made. The intent was primarily to create a historical reconstruction, but there was also an ethnographic element, since I wanted to understand not only what happened, but how the interviewees understood the social forces they were up against and the strategic reasons for their actions. Of the thirty people I interviewed, seventeen people were affiliated with USAS as members or staff, six with the WRC, six with an organization called SweatFree Communities (which I do not cover here for reasons of space), and sixteen with miscellaneous allied organizations such as the apparel union UNITE HERE and the US Labor in the Americas Project (USLEAP). This may seem like it adds up to well over thirty, but twelve of my respondents were affiliated with multiple anti-sweatshop organizations during their activist careers. For instance, Agatha Schmaedick was a member of USAS at the University of Oregon and later went to work for the WRC as an international factory inspector. For practical reasons of time, finances and linguistic ability, I confined this study to US-based organizations, not attempting to study the entire global network of the anti-sweatshop movement. Most of the US activists I spoke with, however, had spent a considerable amount of time abroad and had worked closely with a number of groups in the Global South.

My second major source of data was historical research using newspaper articles, various groups' reports and websites, and other such material to help me further reconstruct some events, such as specific campaigns, in detail.

Although I conducted my interviews in 2007, this work still remains relevant. Relatively little scholarly work has been written on the history of USAS and the WRC, both important social movement organizations, and this article helps to fill that gap. On the other hand, the issues that USAS and the WRC dealt with and upon which I focus in this paper remain important 
for the anti-sweatshop movement, the broader labor movement, and other progressive transnational campaigns and movements. Activists engaging in transnational organizing continue to wrestle with the issues of organization, solidarity, and accountability examined in this paper and scholars continue to study these issues, as can be seen in my review of the literature. An understanding of the anti-sweatshop movement from 1996-2007 is also important to understanding the historical formation of transnational movements today. The anti-sweatshop movement was one of the major streams of the anti-corporate activism of the 1990s; it and other such movements contributed to the formation of the global justice movement in the first decade of the 2000s, which in turn helped give rise to the on-going climate justice movement. Understanding the dynamics of the anti-sweatshop movement can help us better understand how today's transnational movements evolved.

\section{The Ideology of the Anti-Sweatshop Movement}

USAS has strong ties to the labor movement, with a number of its founders having worked over the summer of 1997 with UNITE (now UNITE HERE), the main US apparel union; as a result of this internship, they became interested in the issue of sweatshops and began organizing around it when they returned to campus in the fall. This connection in turn had a profound effect on the way USAS's leadership looks at the issue of sweatshops. One of the things that struck me in my interviews with student and union-based activists was how much they shared a common ideology, that the only effective, long-term way to abolish sweatshops was to empower workers through independent, democratic unions - and that to do so, international solidarity between students and workers, striving for a relationship based on equality, was essential. I probed my interviewees for differences of ideology—and to my 
surprise did not find any. While I of necessity quote only selected interviewees below, the sentiments they express were widely held among my interviewees and I did not come across any dissenting viewpoints.

Some may question whether this set of beliefs and norms truly constitutes an ideology as the word is often used, referring to such systems of thought as anarchism, conservatism, fascism, liberalism, or socialism. While the anti-sweatshop movement's beliefs are not a "grand ideology" in this sense, they nonetheless constitute a coherent set of beliefs about the social and political world, one which guided their strategic actions in ways much deeper than a frame simply used to recruit people; I therefore find it most illuminating to apply the concept of ideology to this set of beliefs, rather than that of discourse or frame.

There are, of course, a variety of attitudes held by workers about how to improve their lot, some of which qualify as ideologies and others perhaps better thought of as a set of attitudes not well articulated enough to be an ideology. Based on a study of women workers in two Thai sweatshops, Pangsapa (2007) identifies four broad understandings of their situation sweatshop workers may have - acquiescence, accommodation, resistance, and alienation. Acquiescence indicates that the women workers fully accept the social system and their subordination in it. Accommodation indicates that the women workers not only accept the system, but feel empowered by it. They seek to work within the system, advancing themselves through individualistic means such as working additional overtime. Pangsapa found that one factory owner was able to foster this accommodationist attitude by acting in paternalistic ways such as keeping the facility clean, allowing workers days off for family or medical emergencies, etc. This lead workers to identify with the factory owner, rather than developing an adversarial relationship. Resistance indicates that the women workers believe that the system is unjust and 
that they can change it through collective action. Alienation indicates that the women workers feel the system is unjust, but that there is nothing they can do to change it. In his study of Latin American labor movements, Anner (2011) looks at the different forms ideologies of resistance can take. He places them on spectrum from left-wing ones that emphasize class conflict and an adversarial relationship with business owners to more centrist and conservative approaches that take a cross-class collaborationist approach, with unions trying to work in partnership with business owners. The latter is distinct from the accommodationist mentality described by Pangsapa, for there workers focus on advancing themselves individually, rather than taking collective action to better their lot.

The anti-sweatshop movement's ideology falls to the left wing of Anner's (2011) spectrum. In terms of the elements of ideology as defined by Oliver and Johnston (2000), the anti-sweatshop movement's beliefs break down as follows: 1) a set of values emphasizing worker empowerment; 2) an analysis critiquing sweatshops as a structural problem in the apparel industry, not a matter of a few bad actors; and 3) the norms of promoting independent, democratic unions through which workers can protect their rights; and students acting in solidarity with, instead of paternalistically on behalf of, workers. While most labor unions and other labor groups would likely say they intended to empower workers, in addition to the emphasis on class conflict, the structural critique of the industry and the emphasis on transnational coalition-building makes this approach distinct from the more conservative, crossclass collaborationist approach described by Anner. I refer to it as an ideology of worker empowerment because of the unexpected finding of the student activists who were the focus on much of my interviewing universally emphasizing the importance of empowering workers through labor unions, rather than taking a more paternalistic approach to sweatshop workers. 
This core value of worker empowerment means that workers should be able to control their own lives and should be able to exercise their own power, not needing to rely on the goodwill of others to guarantee their well-being. For instance, USAS member Laura McSpedon (interview, 2007) told me, "The long-term goal for me was to create a structure and to create systems that opened up space for workers to organize in a way that it was closed when we started." The anti-sweatshop movement's social analysis consists of a sophisticated sociological understanding of how existing social systems foster sweatshops and disempower and exploit workers, necessitating large-scale structural change in the global economy. For example, Eric Dirnbach of UNITE HERE (interview, 2007) said the problem was that, "the entire business model is a model that creates sweatshops. There's tremendous price pressure on the contracting factories to lower the prices they will charge for the apparel, which means wages have to be lowered." This analysis closely follows the one laid out earlier in this paper.

As an example of the movement's norm of supporting independent unions, one anonymous interviewee (interview, 2007) told me that central to the work of USAS is "the belief that if workers are able to exercise their right to organize without management interference then the chances of seeing other rights respected is much greater because they can advocate for themselves in the factory, dealing with management directly when an independent monitor is not there- and most of the time monitors are not there." In other words, it is workers' right to organize through independent, democratic labor unions which serves as the guarantee of all other rights. On the norm of solidarity, USAS member Jessica Rutter (interview, 2007) told me, "Overall, what we do is about student-worker solidarity and using the power of the university to support worker demands — that's the very core of it." This understanding of solidarity as supporting worker demands is rooted in a belief in the importance of avoiding paternalism on the 
part of students, instead striving for a relationship based on accountability by students to workers in order to empower the latter.

This ideology can be contrasted with that of the Fair Labor Association. (See Figure 1.) The FLA sees no need to empower workers, with the companies in the FLA viewing the organization as a substitute for unions. The FLA also lacks any sort of structural critique of the apparel industry. Indeed, they represent members of the industry as having an interest in and the insider knowledge necessary to solve the problem of sweatshops. For instance, Roberta Karp of Liz Claiborne defended the inclusion of apparel firms in the FLA's monitoring process: "You need buy-in from the people who have a stake in this. [...] Corporations have a stake in protecting their names and making sure the facilities they contract with are operated fairly, efficiently and effectively" (quoted in Snyder 2000). The member corporations of the FLA tend to shift the blame for sweatshops from themselves to poor practices by their contractors. As a result, the FLA sees no need for worker involvement in its operations and treats its programs as a substitute for labor unions. The FLA treats workers not as a necessary part of the solution, but passive victims in need of help.

[Insert Figure 1 here]

\section{The Anti-Sweatshop Movement's Transnational Organization}

It is important to understand that the principles of the anti-sweatshop movement are not only a matter of values, but instrumental as well-anti-sweatshop activists argue that empowering workers is not only ethically desirably in and of itself, but strategically the only way to effectively fight sweatshops over the long-term. This ideology powerfully shapes the way USAS and other US anti-sweatshop groups engage in transnational organizing. One key element 
of the anti-sweatshop movement's model for transnational organizing is that workers in the Global South and organizations that represent them - not only unions, but NGOs with close ties to them - should be centrally involved in these networks and that other groups should be accountable to them. Thus, in the decision-making processes within these networks, they emphasize letting groups representing sweatshop workers set the basic agenda and goals that the network seeks to achieve. (See Figure 2.)

[Insert Figure 2 here.]

\section{Bridge-Workers and Transnational Social Movement Networks}

Crucial in building such ties are people referred to by different scholars as either bridgeworkers (McCammon 2012; Ryan 2005) or brokers (McAdam, Tarrow, and Tilly 2001; Von Bülow 2011), terms for those who play a critical role in linking together organizations from different global locations. Without a bilingual bridge-worker, it can be difficult to maintain communication. Important records documenting labor abuses will go un-translated and not get to first-world activists. It is also next to impossible to sustain long-term relationships between local activists and ones in the Global North. Without this, it is impossible to strategize in such a way as to ensure that the workers are helping to shape the agenda. It is also difficult for Northern activists to get regular information on conditions on the ground for those they seek to help (Robertson and Plaiyoowong 2004). In the Kukdong campaign, both Jeff Hermanson of the AFL-CIO Solidarity Center and Evelyn Zepeda of USAS played this role, providing a conduit through which USAS and their allies could understand the workers' goals and concerns and thus to try to ensure that they were at the heart of their campaign. Conversely, the FLA appears to have had no such connections to the workers at the Choishin factory. 
This structure allows the groups involved to exchange local knowledge, which has been crucial to the success of the movement and the evolution of their strategy over time. Hermanson (interview, 2007) of the Solidarity Center stressed that their allies in the Global South "don't just provide us with an understanding of what's going on in their country, they also participate in the development of a global strategy. They're students of the global production system just as much as we are in the US."

\section{USAS' Transnational Networks}

In order to strengthen their partnerships with allies in the Global South, USAS initiated an internship program. According to USAS member Liana Dalton (interview, 2007), such internships were crucial to maintaining USAS's relationships with its partners abroad. "The interns are the ones that actually build the trust and relationships with their host organizations over the course of the two months that they're with them and then they serve as the liaison throughout the year. We conceptualize our international intern program as not a two-month program but a year-long internship." Zack Knorr, a national organizer for USAS, said that one of the biggest reasons that USAS decided to implement the internship program was "that we are an organization of students primarily in the U.S., also in Canada, but our demands and what we do really needs to be driven by workers on the ground [...]. If we're not connected to them then we're not doing that." For USAS, their internship program was another means to empower their partners in the Global South.

Through the internships, USAS tried to institutionalize the sort of bridge-worker relationship that Zepeda had with the Kukdong workers when she went to live with them. While in the field, the interns served their host organizations in a number of ways, ranging from 
interviewing sweatshop workers; contributing their English language, computer, and other technical skills; helping maintain communications abroad; and simply helping around the office. Upon their return to the US, in addition to maintaining their role as a liaison, they tried to convey what they learned in their internship to other members of USAS, both in the leadership and in the grassroots base.

\section{The WRC's Transnational Networks}

In recent years, as USAS has become more domestically focused, trying to help workers facing exploitive conditions on college campuses fight for their rights, they have let the internship program lapse. The WRC, however, continues to maintain extensive global ties through its team of international factory inspectors. The inspectors in turn rely on workers in the factories or groups with ties to workers in the factories to alert them to possible violations of labor rights standards that would lead them to launch an investigation. These groups with ties to workers are, in the words of Agatha Schmaedick (interview, 2007), a former investigator for the WRC, the Consortium's "local eyes and ears on the ground." Groups and people who serve as the WRC's local contacts include "unions, community organizations, faith-based organizations, women's rights organizations, [and] doctors who work in occupational health and safety" (Schmaedick, interview, 2007). During their inspections, the WRC works closely with such allies, making them part of their inspection teams so as to be able to draw on their ties with workers and expertise on local conditions. (To avoid conflicts of interest, however, the WRC does not directly involve groups that reported a violation of workers rights in the inspections related to that complaint.)

The WRC also seeks to use their monitoring to build the capacity of local labor unions 
and other labor rights groups, so there is less need for a reliance on outside inspectors like the WRC. Schmaedick (interview, 2007), for instance, stressed the importance of "setting up internal grievance systems within the factory that really work, making sure there's new respect [...] formed between management and the workforce, and that the workforce has a voice-an organized voice - in the workplace, so they can address grievances in real time and rely less and less on external monitors such as myself."

\section{The FLA's Lack of Networks}

As noted earlier in the paper, the FLA's former executive director van Heerden implicitly admitted the FLA lacked any such networks. And, while they have developed programs to help contractors better comply with lead firms' codes of conduct, they do not have any programs like the WRC's meant to build the capacity of labor unions or other labor rights groups. Empowering workers is not part of the FLA's operational goals.

\section{The Anti-Sweatshop Movement's Strategizing Process}

\section{Organization and Strategizing}

Once US and third-world activists have built the necessary ties with each other and formed transnational networks, the organizational model is to make decisions by consensus, drawing on the knowledge and experience of all the network's members. At least in principle, the concerns of the workers on the ground, involved in struggles to unionize, are privileged, in that they help the network set its priorities. Long-time labor activist Stephen Coates (interview, 2007) told me, for example, of one campaign: "We had a couple of conflicts with partner organizations that wanted to call for a boycott. We said, 'Well, that's not what the workers want. 
You may think that that's effective, but it's sort of a knee-jerk response, that's not going to work here.' I think most people come around to that view."

Boycotts, of course, have been useful in many circumstances historically and neither Coates nor other anti-sweatshop activists are opposed in principle to them. Indeed, there have been cases where the movement has used boycotts—-but they do so only in particular, somewhat unusual strategic circumstances. The reason the movement generally doesn't use boycotts is because of workers' concerns that they could end up putting them out of work permanently. Obviously, this is not what they want. Rather, they are looking for ways to pressure the major apparel firms that will not result in a loss of orders for their factory, if it can helped. USAS, for instance, in the Kukdong and other such campaigns has relied on the threat of suspension of apparel firms' licenses, rather than an actual permanent cancelation of them. The goal is to ensure that workers can continue producing college-licensed goods, only under better conditions - not to end their relationship with colleges. Only in handful of cases, such as particular campaigns involving Russell Athletics, Adidas, and Nike, has USAS launched a fullscale boycott and, in those instances, the companies had already fired en masse the workers USAS sought to support, so the workers had nothing left to lose from a boycott (Blaskey and Gasper 2012; Garwood 2011; Greenhouse 2009, 2010; MacLaren 2013). The potential problems with a boycott in the wrong circumstances are not obvious to most activists, however, and without ties to workers, US activists would probably not realize this and incorporate this understanding into their strategy. Here we can clearly see how the US anti-sweatshop movement's goals of accountability to and the empowerment of sweatshop workers shapes their strategy. 


\section{The Designated Suppliers Program}

Informed by what their partners in labor rights groups in the Global South told USAS interns and other members of their groups, in 2005 there was an attempt by USAS and the WRC to significantly retool their strategy by unveiling the Designated Suppliers Program (DSP). As working conditions in factories improved, the cost of doing business with them would go up, and the lead apparel firms would take their orders elsewhere. The result was that at many factories where workers had won important victories with the support of the global anti-sweatshop movement, the workers found themselves out of work as the factory closed for lack of business. Rutter (interview, 2007) said, "With a lot of the really important relationships that had been built with workers at certain factories, those workers were saying, 'We really need to keep our factory, that's the most important thing right now."' According to Rutter, this request required a rethinking of USAS's strategy, since it "was really different than anything USAS had ever done before, because USAS generally didn't work to keep business in certain places, that's just not what we did —we supported workers organizing." Getting into details of the DSP is beyond the scope of the paper (see Designated Suppliers Program Working Group (2006) and Williams (2016, 2020) for such details), but in brief, it was an attempt by USAS, the WRC and their allies to ensure the victories they were winning at individual factories were more long-lived.

USAS and the WRC designed the DSP as a system under which companies producing licensed apparel for WRC-member schools would have to outsource their production 1) in such a way as to pay the factory owners at a rate sufficient to give them the ability to treat workers well, making the lead firms responsible for working conditions in their contractors' factories; and 2) establish long-term relationships with those factories, ensuring they would keep their business if they improved working conditions, despite the resulting increased production costs. 
Additionally, 3) factory-owners, particularly ones that had engaged in union-busting in the past, would also have to make it explicitly clear that workers were now welcome to unionize. 4) Workers would be in a position to de-certify their factory — which could then no longer produce college apparel for WRC-affiliated schools—-by filing a complaint with the WRC, giving them greater potential leverage over not only their immediate employers but the lead apparel firms. The DSP itself was designed collaboratively by USAS, the WRC, and their allies, including many labor groups from the Global South. The process started with a series of e-mail exchanges and conference calls and culminated in a January 2005 retreat of roughly fifty people, including not only members of USAS and the WRC, but representatives of a range of labor rights groups, including those from the Global South. After a certain point, however, the allies from the Global South were effectively unable to participate, because once it came to hammering the technicalities of how the DSP would work as a program of US colleges, Southern labor unions simply did not know enough to contribute. Dalton (interview, 2007) explained:

I think the core demands come from the unions and the partners in the South. $[\ldots]$ The necessity of student organizing has forced us to create this entity, the DSP. [...] A lot of unions don't have a good enough conception of the organizing reality of students and administrators relations--they don't understand why some of these decisions are being made. Therefore it's really difficult to continue that consultation process.

Due to resistance not only from businesses, but college administrators with close ties to business, and the DSP's ambiguous standing under anti-trust laws until the matter was clarified by the Obama administration in 2011 (six years after the launch of the DSP), the campaign to implement the DSP stalled out. While USAS did succeed in getting some schools to sign onto 
the DSP, it never reached the critical mass necessary to make it a viable program.

\section{The Accord on Fire and Building Safety in Bangladesh}

Despite the campaign for the DSP stalling out, it still left an important strategic legacy, with other projects being informed by it. One important example of this is the Accord on Fire and Building Safety in Bangladesh (WRC Executive Director Scott Nova, personal communication, June 30, 2019), a legally binding agreement signed in 2013 by 200 major transnational apparel firms, both local and global unions, and a number of labor rights groups, including the WRC. The Accord was reached after a series of high profile disasters, such as the Tazreen factory fire and the Rana Plaza collapse, in which in which large numbers of workers died (1,134 at Rana Plaza) in cases that would have been prevented if basic safety protocols had been followed by the factory owners. A number of the things global apparel firms are legally bound to do under the Accord were informed by the standards of the DSP. Specifically, if Bangladeshi factory owners were unable to afford to upgrade the safety standards of their factories, the lead apparel firms had to fund the upgrades, making them ultimately responsible for the health and safety conditions in their contractor's factories. Independent, democratic labor unions representing the workers had to be trained in global safety standards and actively involved in the inspection processes, thereby allowing workers to certify whether the conditions they are working under are safe or not (Accord on Fire and Building Safety in Bangladesh 2015; Brown 2015; Nova 2014; Rahman 2014).

Unfortunately, despite, or perhaps because of, its ground-breaking approach, the Accord is no longer active. While some of the partner European firms remained committed to it, the Bangladeshi government and Bangladeshi factory-owners remained hostile to it. The 
Bangladeshi government refused to let the Accord to remain in operation past March 2020, taking over its operations, despite being woefully unprepared in terms of the number and training of staff to do so, to say nothing of the government's close ties to factory-owners, which means it is not, in practice, an independent inspector (Bair, Anner, and Blasi Forthcoming (2020)).

In general, as with the DSP, workers' input in the broader transnational strategy must be limited in some ways, even as they shape the broad contours of the campaign. Workers certainly determine their own strategy locally—but they cannot determine strategy in the US. This is for the simple reason that they have relatively limited knowledge of the US and so they must leave that part of the strategizing to US groups. Because workers in the Global South cannot really help plan strategy in the US, it is all the more important that they and local NGOs allied with them feel like they can trust US groups to be accountable to workers' concerns and not displace them with those of US activists. It is important that when sweatshops workers told US allies they opposed a boycott for fear of losing their jobs, that their US allies listened and looked for another strategy. It is important that when USAS' allies in Global South were reporting that their victories were ephemeral and that they needed to find a way to keep factories where they had won substantial gains open, USAS worked in consultation with them to develop a new strategy that tried to tackle this problem. The focus by USAS and other US anti-sweatshop groups on empowering workers means that their strategy is fundamentally shaped by feedback from sweatshop workers and organizations representing them on what their needs and aspirations are and what tactics they are comfortable with. Because the US anti-sweatshop movement makes an effort to center the goals of sweatshop workers, there strategy is more effective. Their initial model of activism was successful in helping them win victories in individual factories; and the model that was created with the DSP and implemented with the Bangladesh Accord was 
successful in putting in place more long-term solutions - or would have been if it had been able to continue.

\section{Discussion}

In this paper, I explored why anti-sweatshop activists chose their particular strategy, emphasizing their ideology of worker empowerment and the strategic consequences of this for the success and failure of transnational campaigns. A number of scholars (Downey and Rohlinger 2008; Epstein 1991; King 2008; Maney 2012; Williams 2016, 2020) have emphasized the importance of ideology in shaping activists' strategy. What I add here is the way the antisweatshop movement's ideology of worker empowerment shapes the organizational of their transnational networks - and how the resulting decision-making structure also informs their strategy. Ideology not only directly shapes their strategy but also in a mediated fashion through their organization. Other researchers (Anderson 2000; Friedman 2009; Pallas 2017; Steffek and Hahn 2010) have established that, depending on what actions they take and how transnational networks are organized, the actions of activists from the Global North can empower or disempower their partners in the Global South. In this paper, I have argued that one of the mediating factors in this is again ideology—-specifically, whether activists in the North are ideologically committed to empowering their allies in the South. While such a commitment does not guarantee anything, it does mean activists from the Global North are more likely to try to empower their partners within transnational networks and prioritize Southern groups' goals.

More specifically, I argue that the movement's ideology of worker empowerment and solidarity is essential in helping them see what organizational forms make strategic sense. Democratic network structures that foster communication, accountability, and representativeness 
matter not only for normative reasons, but because such organizational choices shape how transnational networks make strategic decisions within a campaign — what specific tactics they use within the context of a broader strategic model, such as whether to employ a boycott or not. As we saw with the FLA in Choishin, an ideology that does not prioritize empowering and engaging with workers results in a set of monitoring practices that, while legitimating the companies involved with the FLA, does little to actually help workers. USAS and its allies, conversely, have in campaigns like Kukdong incorporated workers' concerns centrally into their efforts and have, as a result, been relatively successful.

I began this paper by noting that the US anti-sweatshop movement, particularly United Students Against Sweatshops, has generally avoided the use of boycotts in their efforts to help sweatshop workers. This is a good example of the way USAS' emphasis on worker empowerment has shaped their strategy. The decision not to use boycotts under normal circumstances is a striking strategic decision, given that this is one of the strategic tools most familiar to progressive activists in the US. Instead, USAS has gone another route, relying on the institutional consumer power of colleges to pressure the major apparel firms to change their policies. When using the institutional consumer power of colleges, USAS relies on the threat of a suspension of the license apparel firms hold to produce college-branded goods-rather than an actual suspension, which would amount to an institutional boycott. The economic leverage is still there, but it remains potential—and thereby not threatening workers' jobs. And the goal is always to get the company in question to fix the problem, so the license can be unsuspended, rather than to cancel it and permanently sever ties with the company. This is obviously a fine line for anti-sweatshop activists to walk, but so far it has been an effective strategy. But they may well not have been aware of the need to walk this line without their commitment to worker 
empowerment and therefore without their communication networks allowing them to learn about and remain accountable to workers' needs and aspirations, particularly workers' concerns about boycotts.

In looking at the intersection of ideology and strategy, the case I focus on here is perhaps atypical in that anti-sweatshop activists in the Global North are conscience constituents - they have no direct material interest in eliminating sweatshops. Looking at activists in the Global South — in particular, sweatshop workers and the unions representing them-would doubtless reveal that workers' material interests are also an important element in how they strategize. But what a group's material interests are and how best to protect them are never transparent — there is always a process of interpretation that social groups must go through to determine what their materials interests are and how best to pursue them, a process that is ideologically loaded (Blyth 2002). Anner (2011), for instance, shows that Latin American labor unions operating in the same industries adopt quite different strategies depending on whether they have leftist, class struggle or more centrist-to-conservative, cross-class collaborationist ideologies. Questions of empowerment will factor into this as well—how much workers need to be empowered and the best way to do so. Workers who see things in terms of what Pangsapa (2007) calls accommodation, for instance, will not see empowerment as important, since they rely on the benevolence of the factory owner to protect them. A fruitful direction for future research would be to look at how a group's material interests interact with their ideology in shaping decisions about organization and strategy, whether in a transnational context or a more national or local one.

A number of scholars (Anderson 2000; Pallas 2017; Steffek and Hahn 2010) have shown that activists in the Global North are not always accountable to the groups in the Global South 
they supposedly seek to support. It would be easy to be cynical and assume that, in light of the power inequalities, groups in the North will always disregard those in the South in pursuing their own agenda, thereby disempowering them. Ideology, however, can serve as a mediating factor, shaping the degree to which groups in the North are accountable to those in the South and thereby able to genuinely empower their allies. As Katzenstein (1998) shows, accountability runs not only along financial and organizational lines, but can run along ideological lines as wellactivists can hold themselves accountable to living up to certain beliefs and meeting the expectations of fellow activists, even when the latter cannot exercise formal power over the former. Thus USAS and the WRC made a concerted effort to remain accountable to their worker allies in the South due to their sense of solidarity with them. Such a commitment to solidarity, accountability, and empowerment does not solve all problems - the process of accountability is not a deterministic one and even Northern groups that seek to be accountable and empowering will have their failures. But an ideological commitment to empowerment does change the dynamic of the relationship between groups. An interesting avenue for future research might be to look at those conditions under which ideology works to make groups more accountable to less powerful allies and those under which it fails to do so, despite good intentions.

\section{References}

Accord on Fire and Building Safety in Bangladesh. 2015. "Signatories." Dhaka, Bangladesh: Accord on Fire and Building Safety in Bangladesh. Retrieved June 23, 2016 (http://bangladeshaccord.org/signatories/).

Anderson, Kenneth. 2000. "The Ottawa Convention Banning Landmines, the Role of International Non-Governmental Organizations and the Idea of International Civil 
Society." European Journal of International Law 11:91-120.

Anner, Mark. 2011. Solidarity Transformed: Labor Responses to Globalization and Crisis in Latin America. Ithaca NY: Cornell University Press.

—. 2012. "Corporate Social Responsibility and Freedom of Association Rights: The Precarious Quest for Legitimacy and Control in Global Supply Chains." Politics and Society 40:609644.

Bair, Jennifer, Mark Anner, and Jeremy Blasi. Forthcoming (2020). "Private Regulation in the Shadow of the State: The Political Economy of Supply Chain Labor Governance in PostRana Plaza Bangladesh." ILR Review 73.

Bandy, Joe and Jackie Smith. 2005. "Factors Affecting Conflict and Cooperation in Transnational Movement Networks." Pp. 231-252 in Coalitions Across Borders: Transnational Protest and the Neoliberal Order, edited by J. Bandy and J. Smith. Lanham MD: Rowman \& Littlefield Publishers.

Barrientos, Stephanie and Sally Smith. 2007. "Do Workers Benefit from Ethical Trade?: Assessing Codes of Labour Practice in Global Production Systems." Third World Quarterly 28:713-729.

Benjamin, Medea. 2000. "Toil and Trouble: Student Activism in the Fight Against Sweatshops." Pp. 237-252 in Campus, Inc.: Corporate Power in the Ivory Tower, edited by G. D. White. Amherst NY: Prometheus Books.

Blaskey, Sarah and Phil Gasper. 2012. "Campus Struggles Against Sweatshops Continue: Indonesian Workers and U.S. Students Fight Back Against Adidas." Dollars \& Sense, September/ October, pp. 6-8.

Blyth, Mark. 2002. Great Transformations: Economic Ideas and Institutional Change in the 
Twentieth Century. New York: Cambridge University Press.

Bob, Clifford. 2001. "Marketing Rebellion: Insurgent Groups, International Media, and NGO Support." International Politics 38:311-334.

Bonacich, Edna, Lucie Cheng, Norma Chinchilla, and Paul Ong, ed. 1994. Global Production: The Apparel Industry in the Pacific Rim. Philadelphia: Temple University Press.

Brown, Garrett. 2015. "Bangladesh: Currently the Worst, but Possibly the Future's Best." New Solutions 24:469-473.

Designated Suppliers Program Working Group. 2006. "Designated Suppliers Program--

Revised." Worker Rights Consortium, Washington, DC. Retrieved September 14, 2009 (http://www.workersrights.org/dsp/).

Downey, Dennis J. and Deana A. Rohlinger. 2008. "Linking Strategic Choice and MacroOrganizational Dynamics: Strategy and Social Movement Articulation." Research in Social Movements, Conflicts and Change 28:3-38.

Downey, Gary L. 1986. "Ideology and the Clamshell Identity: Organizational Dilemmas in the Anti-Nuclear Power Movement." Social Problems 33:357-373.

Epstein, Barbara. 1991. Political Protest and Cultural Revolution: Nonviolent Direct Action in the 1970s and 1980s. Berkeley: University of California Press.

Esbenshade, Jill. 2004. Monitoring Sweatshops: Workers, Consumers, and the Global Apparel Industry. Philadelphia: Temple University Press.

Ferree, Myra Marx. 1992. "The Political Context of Rationality: Rational Choice Theory and Resource Mobilization Theory." Pp. 29-52 in Frontiers in Social Movement Theory, edited by A. D. Morris and C. M. Mueller. New Haven: Yale University Press.

Ferree, Myra Marx and David A. Merrill. [2000] 2004. "Hot Movements, Cold Cognition: 
Thinking About Social Movements in Gendered Frames." Pp. 247-261 in Rethinking Social Movements: Structure, Meaning, and Emotion, edited by J. Goodwin and J. M. Jasper. New York: Rowman \& Littlefield Publishers.

Friedman, Eli. 2009. "External Pressure and Local Mobilization: Transnational Activism and the Emergence of the Chinese Labor Movement." Mobilization 14:199-218.

Ganz, Marshall. 2009. Why David Sometimes Wins: Leadership, Organizing, and Strategy in the California Farm Worker Movement. New York: Oxford University Press.

Garwood, Shae. 2011. Advocacy Across Borders: NGOs, Anti-Sweatshop Activism, and the Global Garment Industry. Sterling VA: Kumarian Press.

Gereffi, Gary and Miguel Korzeniewicz, ed. 1994. Commodity Chains and Global Capitalism. Westport CT: Praeger.

Gereffi, Gary and Joonkoo Lee. 2016. "Economic and Social Upgrading in Global Value Chains and Industrial Clusters: Why Governance Matters." Journal of Business Ethics 133:2538.

Gereffi, Gary and Xubei Luo. 2016. "Assessing the Risks and Opportuniites of Participation in Global Value Chains." Pp. 152-170 in Achieving Workers' Rights in the Global Economy, edited by R. P. Appelbaum and N. Lichtenstein. Ithaca NY: Cornell University Press.

Good Electronics. 2013. "With Apple the FLA is Not Convincing as a Multi-Stakeholder Initiative." Amsterdam: Good Electronics. Retrieved August 22, 2019 (https://goodelectronics.org/with-apple-the-fla-is-not-convincing-as-a-multi-stakeholderinitiative/).

Greenhouse, Steven. 2009. "Labor Fight Ends in Win for Students." The New York Times, November 17, 2009. Retrieved August 11, 2011 
(http://www.nytimes.com/2009/11/18/business/18labor.html).

—. 2010. "Pressured, Nike to Help Workers In Honduras." The New York Times, Jul 27, pp. B1. Retrieved June 20, 2016 (http://www.lexisnexis.com).

Hermanson, Jeff. 2009. "International Solidarity in the Struggle for Justice at Kukdong in Mexico." Writers Guild of America, West, Los Angeles. Unpublished manuscript.

Katzenstein, Mary Fainsod. 1998. Faithful and Fearless: Moving Feminist Protest Inside the

Church and the Military. Princeton, NJ: Princeton University Press.

King, Leslie. 2008. "Ideology, Strategy and Conflict in a Social Movement Organization: The Sierra Club Immigration Wars." Mobilization 13:45-61.

Kniffin, Kevin. 2000. "The Goods at Their Worst: Campus Procurement in the Global Pillage." Pp. 36-50 in Campus, Inc.: Corporate Power in the Ivory Tower, edited by G. D. White. Amherst NY: Prometheus Books.

Locke, Richard M., Matthew Amengual, and Akshay Mangla. 2009. "Virtue out of Necessity?: Compliance, Commitment, and the Improvement of Labor Conditions in Global Supply Chains." Politics and Society 37:319-351.

Locke, Richard M., Fei Qin, and Alberto Brause. 2007. "Does Monitoring Improve Labor Standards?: Lessons From Nike." Industrial and Labor Relations Review 61:3-31.

MacLaren, Caitlin. 2013. "Adidas Caves, Pays Garment Workers What They're Owed." May 2, Detroit: Labor Notes. Retrieved May 17, 2018 (http://abornotes.org/blogs/2013/05/adidas-caves-pays-garment-workers-what-they-reowed).

Maney, Gregory M. 2012. "Agreeing for Different Reasons: Ideology, Strategic Differences, and Coalition Dynamics in the Northern Ireland Civil Rights Movement." Pp. 170-196 in 
Strategies for Social Change, edited by G. M. Maney, R. V. Kutz-Flamenbaum, D. A. Rohlinger, et al. Minneapolis: University of Minnesota Press.

McAdam, Doug, Sidney Tarrow, and Charles Tilly. 2001. Dynamics of Contention. New York: Cambridge University Press.

McCammon, Holly J. 2003. "'Out of the Parlors and into the Streets': The Changing Tactical Repertoire of the U.S. Women's Suffrage Movements." Social Forces 81:787-818.

-. 2012. The U.S. Women's Jury Movement and Strategic Adaptation: A More Just Verdict. New York: Cambridge University Press.

Nova, Scott. 2014. "Testimony of Scott Nova, Hearing on 'Prospects for Democratic Reconciliation and Improving Workers' Rights in Bangladesh,' Senate Committee on Foreign Relations." Worker Rights Consortium, Washington, DC. Retrieved June 23, 2016 (http://www.workersrights.org/university/Nova\%20Testimony\%202.11.14.pdf).

O'Rourke, Dara. 2003. "Outsourcing Regulation: Analyzing Nongovernmental Systems of Labor Standards and Monitoring." The Policy Studies Journal 31:1-29.

Oliver, Pamela E. and Hank Johnston. 2000. "What a Good Idea!: Ideologies and Frames in Social Movement Research." Mobilization 5:37-54.

Pallas, Christopher L. 2017. "Inverting the Boomerang: Examining the Legitimacy of NorthSouth-North Campaigns in Transnational Advocacy." Global Networks 17:281-299. Pangsapa, Piya. 2007. Textures of Struggle: The Emergence of Resistance Among Garment Workers in Thailand. Ithaca NY: Cornell University Press.

Pearson, Ruth and Gill Seyfang. 2001. "New Hope or False Dawn?: Voluntary Codes of Conduct, Labour Regulation and Social Policy in a Globalizing World." Global Social Policy 1:49-78. 
Polletta, Francesca. 2005. "How Participatory Democracy Became White: Culture and Organizational Choice." Mobilization 10:271-288.

Rahman, Md Zillur. 2014. "Accord on 'Fire and Building Safety in Bangladesh': A Breakthrough Agreement?" Nordic Journal of Working Life Studies 4:69-74.

Robertson, Jr., Philip S. and Somsak Plaiyoowong. 2004. "The Struggle of the Gina Workers in Thailand: Inside a Successful International Labour Solidarity Campaign." Working Paper No. 75, The Southeast Asia Research Centre (SEARC) of the City University of Hong Kong, Kowloon Tong, Hong Kong SAR.

Rodríguez-Garavito, César A. 2005. "Global Governance and Labor Rights: Codes of Conduct and Anti-Sweatshop Struggles in Global Apparel Factories in Mexico and Guatemala." Politics and Society 33:203-233.

Ross, Robert J.S. 2004. Slaves to Fashion: Poverty and Abuse in the New Sweatshops. Ann Arbor: University of Michigan Press.

—. 2006. "A Tale of Two Factories: Successful Resistance to Sweatshops and the Limits of Firefighting." Labor Studies Journal 30:65-85.

Ryan, Charlotte. 2005. "Successful Collaboration: Movement Building in the Media Arena." Pp. 115-136 in Rhyming Hope and History: Activists, Academics, and Social Movement Scholarship, edited by D. Croteau, W. Hoynes, and C. Ryan. Minneapolis: University of Minnesota Press.

Seidman, Gay W. 2007. Beyond the Boycott: Labor Rights, Human Rights, and Transnational Activism. New York: Russell Sage Foundation.

Sethi, S. Prakash and Janet L. Rovenpor. 2016. "The Role of NGOs in Ameliorating Sweatshoplike Conditions in the Global Supply Chain: The Case of Fair Labor Association (FLA), 
and Social Accountability International (SAI)." Business and Society Review 121:5-36.

Slaughter, Sheila and Gary Rhoades. 2004. Academic Capitalism and the New Economy: Markets, States, and Higher Education. Baltimore MD: John Hopkins University Press.

Snyder, Susan. 2000. "Penn Agrees to Review Labor Group: Pending a Committee Study, School Will Withdraw From an Association That Students Protested." The Philadelphia Inquirer, February 16, pp. B01. Retrieved April 15, 2009 (http://www.lexisnexis.com).

Staggenborg, Suzanne. 1989. "Stability and Innovation in the Women's Movement: A Comparison of Two Movement Organizations." Social Problems 36:75-92.

Steffek, Jens and Kristina Hahn, ed. 2010. Evaluating Transnational NGOs: Legitimacy, Accountability, Representation. New York: Palgrave Macmillan.

Tsogas, George. 2009. "International Labour Regulation: What Have We Really Learnt So Far?" Relations Industrielles/ Industrial Relations 64:75-94.

van der Ven, Hamish. 2018. "Gatekeeper Power: Understanding the Influence of Lead Firms over Transnational Sustainability Standards." Review of International Political Economy 25:624-646.

Van Dyke, Nella and Holly McCammon, ed. 2010. Strategic Alliances: Coalition Building and Social Movements. Minneapolis: University of Minnesota Press.

Von Bülow, Marisa. 2010. Building Transnational Networks: Civil Society and the Politics of Trade in the Americas. New York: Cambridge University Press.

-. 2011. "Brokers in Action: Transnational Coalitions and Trade Agreements in the Americas." Mobilization 16:165-180.

Weiss, Robert S. 1994. Learning From Strangers: The Art and Method of Qualitative Interview Studies. New York: The Free Press. 
Wells, Don. 2007. "Too Weak for the Job: Corporate Codes of Conduct, Non-Governmental Organizations and the Regulation of International Labour Standards." Global Social Policy 7:51-74.

Westby, David L. 2002. "Strategic Imperative, Ideology and Frame." Mobilization 7:287-304.

Williams, Matthew. 2016. "Strategic Innovation in US Anti-Sweatshop Movement." Social Movement Studies 15:277-289.

—. 2020. Strategizing Against Sweatshops: The Global Economy, Student Activism, and Worker Empowerment. Philadelphia: Temple University Press.

Wood, Lesley J. 2005. "Bridging the Chasms: The Case of People’s Global Action." Pp. 95-117 in Coalitions Across Borders: Transnational Protest and the Neoliberal Order, edited by J. Bandy and J. Smith. Lanham MD: Rowman \& Littlefield Publishers.

Worker Rights Consortium. 2001. "WRC Investigation Re: Complaint Against Kukdong (Mexico): Report and Recommendations." Worker Rights Consortium, Washington, DC. Retrieved June 29, 2009 (http://www.workersrights.org/Freports/Kukdong.asp).

—. 2019a. "Frequently Asked Questions." Washington, DC: Worker Rights Consortium. Retrieved August 26, 2019 (https://www.workersrights.org/affiliates/frequently-askedquestions/).

—. 2019b. "Governance." Washington, DC: Worker Rights Consortium. Retrieved August 26, 2019 (https://www.workersrights.org/about/governance/).

Zald, Mayer N. 2000. "Ideologically Structured Action: An Enlarged Agenda for Social Movement Research." Mobilization 5:1-16. 
Figure 1: The contrasting ideologies of USAS and the FLA

\begin{tabular}{|l|l|l|}
\hline $\begin{array}{l}\text { Elements of } \\
\text { ideology }\end{array}$ & USAS & FLA \\
\hline Values & Worker empowerment & $\begin{array}{l}\text { Paternalistic care for sweatshop } \\
\text { workers as passive victims }\end{array}$ \\
\hline $\begin{array}{l}\text { Analysis of } \\
\text { the problem }\end{array}$ & $\begin{array}{l}\text { The structure of the global apparel industry } \\
\text { fosters the creation of sweatshops and other } \\
\text { labor abuses }\end{array}$ & $\begin{array}{l}\text { Misconduct by the contractors to } \\
\text { whom the lead firms outsource }\end{array}$ \\
\hline $\begin{array}{l}\text { Norms for } \\
\text { action/ } \\
\text { strategy }\end{array}$ & $\begin{array}{l}\text { Solidarity with workers; the promotion of } \\
\text { independent, democratic labor unions }\end{array}$ & $\begin{array}{l}\text { Corporate social responsibility } \\
\text { programs }\end{array}$ \\
\hline
\end{tabular}

Figure 2: The relationship between ideology, solidarity, organization, and strategy in the transnational antisweatshop movement

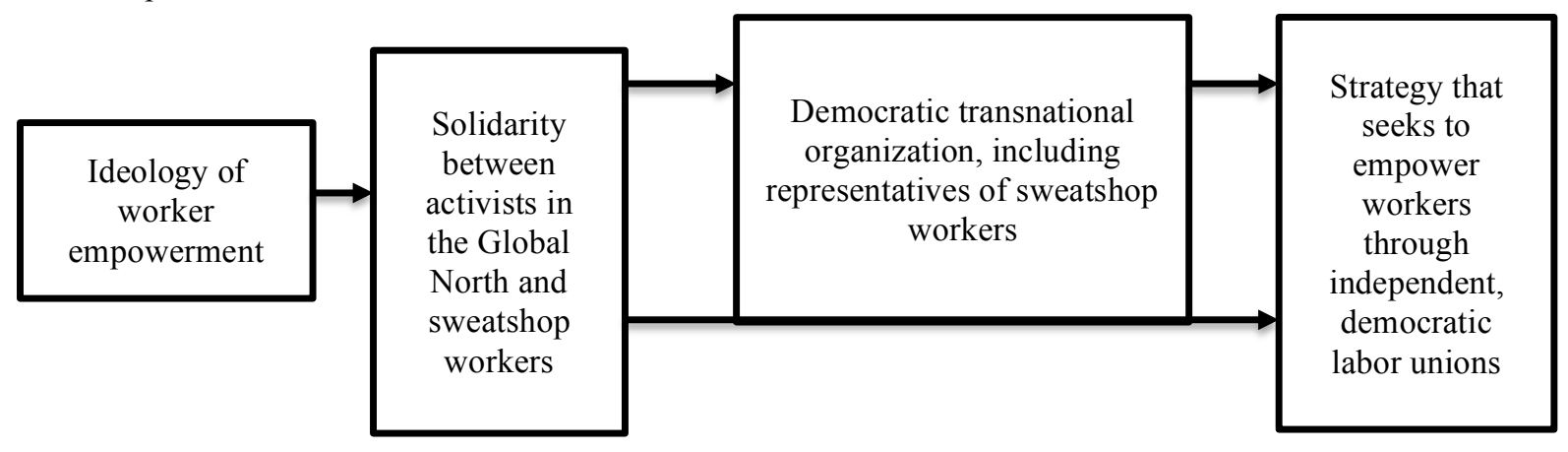

